\title{
INTRODUCTION TO SYMPOSIUM ON FLEUR JOHNS, “DATA, DETECTION, AND THE REDISTRIBUTION OF THE SENSIBLE IN INTERNATIONAL LAW”
}

\begin{abstract}
Maks Del Mar*
This symposium situates a recent AJIL article by Fleur Johns, and develops ideas through and from it. ${ }^{1}$ Johns' article centers on new or newish sensory technologies rather than distant history; yet much can be gleaned about its significance for legal scholarship by comparing it with the work of contemporary historians such as Lauren Benton. ${ }^{2}$ Benton has looked for law in some unlikely places: chronicles of imperial voyages, manuals of colonial administration, and letters and dispatches of middling officials. And she has found it being made and remade with the arguments and lives of sailors and soldiers, settlers and convicts, and bandits and pirates. This is an approach to law that looks for and finds law-using, law-making, and law-circulating in microconflicts over power and authority (for instance, Benton often speaks of "jurisdictional politics"), and that is always sensitive to the unevenness, instability, complexity, polycentricity, and vastness of legal culture.

Like Benton, Johns is interested in "the constitution and exercise of jurisdiction" of international institutions. ${ }^{3}$ Johns also pays careful attention to some unlikely places (unlikely at least to a scholar looking for international law): iris-scanning data and satellite images (described, for instance, in inspection and compliance manuals). And, she casts her net widely in terms of the "who," paying attention to "relatively low-level interactions and formally unqualified agents," 4 and pointing to the importance of invisible or unknown persons exercising "quiet power," 5 e.g., "a lead researcher in the safeguards group at the Forschungszentrum Jülich in Germany.", Unevenness, too, is there, as Johns is very sensitive to what "uneven redistributions" of "power, competence, and capital" are caused by new sensory technologies. ${ }^{7}$
\end{abstract}

* Reader in Legal Theory, Queen Mary University of London.

${ }^{1}$ Fleur Johns, Data, Detection, and the Redistribution of the Sensible in International Law, 111 AJIL 57 (2017).

2 The comparison here was inspired by a visit by Lauren Benton to Queen Mary University of London in May 2017, when we launched her most recent book: Lauren Benton \& Lisa Ford, Rage for Order: The British Empire and the Origins of International Law 1800 1850 (2016). See also her earlier books: Lauren Benton, Law and Colonial Cultures: Legal Regimes in World History 1400-1900 (2002); and Lauren Benton, A Search for Sovereignty: Law and Geography in European Empires 1400-1900 (2009). As Benton acknowledges, her historiography is deeply informed by E.P. Thompson's "history from below" — see E.P. ThOMPSON, THE MAKING OF THE ENGLish WORKING CLASS (1963).

${ }^{3}$ Johns, supra note 1 , at 58 .

${ }^{4}$ Id. at 64 .

${ }^{5}$ There is no doubt that Johns' work shares, as she is aware, many affinities with the recent literature on global and transnational indicators (see, e.g., Governance by Indicators: Global Power through Quantification and Rankings (Kevin Davis et al. eds., 2012)). As Johns put it, however, she seeks to go further, claiming that "sensory practice plays a significant role in sustaining law generally on the global plane, and that it does so by propagating and repropagating inequality." Johns, supra note 1, at 65 .

${ }^{6}$ Johns, supra note 1 , at 89.

${ }^{7}$ Id. at 59.

The American Society of International Law and Maks Del Mar $@$ 2017. This is an Open Access article, distributed under the terms of the Creative Commons Attribution licence (http://creativecommons.org/licenses/by/4.0/), which permits unrestricted re-use, distribution, and reproduction in any medium, provided the original work is properly cited. 
Of course, there are differences - where Benton's work often focuses on conflict and struggle, Johns (at least in this article) is more sensitive to the routine, and the shadows of power in the mundane, the ritualistic, and in the seemingly innocuous techniques of ever-greater technological efficiency. And, Johns is more attuned to the importance of materiality (to "registers and artifacts of governance" $)$ ) and embodiment (for instance, the affective dimension of body-machine interaction). Nevertheless, both Benton and Johns squarely challenge the orthodoxies of legal scholarship — its spaces, its temporalities, its materials, and its agents—with a methodology and aesthetic of the rough ground.

What is the relationship between (international) law and "sensing practices," i.e. "the work of trying to detect and verify certain worldly phenomena"?? That is the basic question asked by this article. What effects do those sensing practices - which we can also think of broadly as encompassing any noticing or recording of people or phenomenahave on the ethics and politics of law? What kinds of things are sensed — what "conditions, persons, patterns" —and how? What counts as information, and how is it elicited, received, and processed? Crucially, who does the sensing? Further, how do changes in those practices create changes in international legal thought, doctrine, and practice? What happens to law and our experience of it when that detection and verification of "facts" happens not through direct human contact, but is instead automated, and supported by complex algorithms of machine learning? We know from the work of Michel Foucault how changes in fact-gathering and evidentiary practices—or, knowledge practices more generally-come arm-in-arm, hand-in-hand, with changes in power structures and dynamics. ${ }^{10}$ We know how important the history of fact-making is for the history of law, power, and capital. What, then, should we make of the "new, technologically advanced modes of data gathering and analysis?"11

Johns makes a compelling case for the undeniable importance of these sensing practices, illustrating how they affect everything from "exercising power to govern, mak [ing] legally significant decisions, and conducting juridical relationships on the global plane." 12 Her article delves into (the devil in) the details: the satellite imagery deployed by the International Atomic Energy Agency (IAEA) to track the global movement of weapons, and the iris-reading technology used by the United National High Commissioner for Refugees (UNHCR) to record the mass movement of refugees. Johns shows patiently, and in multiple dimensions, how changes in sensing practices in both of these domains-weapons and migration, respectively_have led to changes in where and by whom power is being exercised, often in ways that are undetected and invisible. Some place great hope in these technological changes, and although Johns is careful to avoid doom and gloom — she says explicitly that she is working "against hopelessness and foreclosure"13 - it is clear that she thinks we can all too easily be blinded and dazzled by new technology, especially where it is presented or presents itself to us under the guise of neutral, mere, or just technical data. ${ }^{14}$ The "we" here are not only scholars, but also the officials on the ground, whose interactions (for instance, with refugees) are clearly affected by the common, naive belief that "the machine can't make a mistake."

\footnotetext{
${ }^{8} I$ d. at 65.

${ }^{9}$ Id. at 59 .

${ }^{10}$ See also the recent paper by Jan Christoph Sintrup, Michel Foucault and the Competing Alethurgies of Law, 37 OxFORD J. LEGAL STUD. 301 (2017).

11 Johns, supra note 1 , at 59.

${ }^{12} I d$. at 59.

${ }^{13} \mathrm{Id}$. at 67.

14 See also, Johanna Drucker's work, pleading for a critical digital humanities that does not speak of "data," but instead of "capta": Johanna Drucker, Graphesis: Visual Forms of Knowledge Production (2014).
} 
Johns ventures bravely forth, not afraid to confront the "technicalities" of these new technologies on their own terms. ${ }^{15}$ In doing so, she shows us that this kind of work can be done and that it ought to be done more. The five responses collected here will, I hope, not only add to the richness of Johns' research agenda, but, building on her work, show what further themes and questions remain to be investigated.

These themes and questions include the following:

- What is the epistemology of Johns' notion of sensing practices-for instance, just how mediated by language are they, and how do they relate to technology/materiality? Johns asserts that these practices are necessarily mediated by language and that they are inseparable from technology and materiality-it would be interesting to explore this further.

- What is the relation between sensory practices and authority? Johns suggests an intimate link between coherence among sensory practices and the authority of law-this, too, would be fascinating to explore further, not only in the context of these automated forms of data collection, but more historically by reference to other kinds of sensing practices, ${ }^{16}$ and perhaps as compared to other domains of practice (e.g. the authority of science). ${ }^{17}$

- There is the question of how Johns' work challenges the very concept of an "official" - a point picked up on by both Keith Culver ${ }^{18}$ and Gavin Sullivan in their essays, the latter observing that "the implications of algorithmic global governance by a population of low-level officials remains poorly understood."19 Clearly there is scope here for more work on the legal agency exercised by those designing, refining and administrating machines. ${ }^{20}$

- Another theme (picked up in the essays by Elspeth Guild ${ }^{21}$ and Anne Alexander ${ }^{22}$ ) might be the importance of performance and intimacy (of sensing practices) in the life of law, and what happens to law and its authority when it loses the drama of these, and becomes ever more remote and inscrutable to human emotion. In fact, the affective (and also (dis)embodied) dynamics of algorithmic governance are calling out for further inquiry.

${ }^{15}$ See also the work of Annelise Riles (as well as Anne Orford)—and, in this respect, the second part of Gavin Sullivan's comments. See Annelise Riles, A New Agenda for Cultural Law Studies: Taking on the Tecbnicalities, 54 Buff. L. Rev. 973 (2005); Gavin Sullivan, "Taking on the Technicalities" of International Law - Practice, Description, Critique: A Response to Fleur Johns, 111 AJIL Unbound 181 (2017).

${ }^{16}$ As Anne Alexander notes in her comment (see Anne Alexander, Reflections on Sensing Power and Practice: A Response to Fleur Johns, 111 AJIL UNBOund 196 (2017)), by reference to the work of Benedict Anderson (BENEDICT ANDERSON, IMAGINED Communities (1983)), a promising context for such historical work is colonial sensing practice. What would be interesting here is to compare satellite imagery and iris-scanning data to e.g. census tables.

${ }^{17}$ Out of many references, it suffices to mention the work of Lorraine Daston and Peter Gallison. See LorRAINE Daston \& Peter Gallison, OBjectivity (MIT Press, 2007).

18 Keith Culver, Sensing Possibility in International Law - Concepts and Categories for the $21^{\text {st }}$ Century: A Response to Fleur Johns, $111 \mathrm{AJIL}$ UnBound 200 (2017).

${ }^{19}$ Sullivan, supra note 15 .

20 This work would intersect with current interest in the figure of the jurist, including the global jurist (see Neil Walker, The Jurist in a Global Age, in Rethinking Legal Scholarship 84 (Rob van Gestel et al. eds., 2017)); work in progress by Nicole Roughan on officials (not yet published); and work on "office” by Shaun McVeigh (see, e.g., Shaun McVeigh, Afterword: Office and the Conduct of the Minor Jurisprudent, 5 IrvinE L. Rev. 499 (2015)).

${ }^{21}$ Elspeth Guild, The Right to Dignity of Refugees: A Response to Fleur Johns, 111 AJIL UnBound 193 (2017).

22 Alexander, supra note 16. 
- A further theme might be the aesthetics of sensory power - a theme alluded to by Grégoire Mallard in his essay. ${ }^{23}$ Johns speaks of "the dazzle of technology," and it might be worth exploring how to unpack this "dazzle" in aesthetic terms, and again, to compare it historically to other instances of relations between what we count as "data" and what we respond to with aesthetic pleasure. ${ }^{24}$

- Finally, as developed in Culver's essay, there is theme of the regionality of international law, i.e. rather than speaking of or looking for any kind of global coherence (for instance, a global "sensorium" as Johns calls it), it might be more fruitful to investigate regionally-specific sensing practices or regional sensoria (such as the smart global cities of Greater London or Greater Paris). In doing so, we would be well to recall Benton, who has long spoken of regional governance and administration - there is here, then, room for a legal geography of sensory practices.

The delectable prospect of such further inquiries is already enough to signal just how stimulating and challenging Johns' article is. There could be no stronger endorsement than a sudden surge of new questions and themes. I, for one, and clearly also the commentators included in this symposium, will be eager to track the legacy of this article for international legal scholarship and beyond.

${ }^{23}$ Grégoire Mallard, Rules and Monitoring Systems - Complementary or Conflicting Logics?: A Response to Fleur Johns, 111 AJIL UNBOUND 187 (2017).

24 See Orit Halpern, Beautiful Data: A History of Vision and Reason Since 1945 (2015). 